\title{
Endangered even before formally described: Bulbophyllum kubahense n.sp., a beautiful and assumedly narrowly endemic orchid from Borneo
}

\author{
Jaap J. Vermeulen • Anthony Lamb
}

Received: 23 August 2010/Accepted: 20 December 2010/Published online: 19 January 2011

(C) The Author(s) 2011. This article is published with open access at Springerlink.com

\begin{abstract}
B. kubahense J.J. Verm. \& A. Lamb is described, a new species differing from $B$. refractilingue in having a longer rachis, longer lateral sepals and larger petals. This attractive species is known from a single locality within a national park in Sarawak, Malaysia. Nevertheless, wild-collected plants have turned up in nurseries in Singapore, causing concern about its continued existence in the wild.
\end{abstract}

Keywords Bulbophyllum kubahense - Bulbophyllum refractilingue $\cdot$ Endangered species · Wild-collected orchids

Our knowledge of the Borneo orchid flora has increased enormously over the last few decades. Critical checklists for the whole island (Wood and Cribb 1994), parts of it (Wood et al. 1993, Beaman et al. 2001) and generic revisions (e.g., Wood 2001) are now available. Bulbophyllum is partly revised in Vermeulen (1991). More species have been discovered since, and the total number of Bornean Bulbophyllum species is now around 275 (source ASO$\mathrm{RCH}$, our database on SE Asiatic orchids). B. kubahense sp.n., described below, belongs to section Pahudia Pfitzer, a section which largely consists of terrestrial or low-level epiphytic species.

J. J. Vermeulen $(\square)$

National Herbarium Netherlands, Leiden Branch, P.O. Box 9514, 2300 RA Leiden, The Netherlands e-mail: vermeulen@nhn.leidenuniv.nl

A. Lamb

P.O. Box 10960, 88810 Kota Kinabalu, Sabah, Malaysia
The continued existence in the wild of $B$. kubahense is a cause of concern. The species is known from a single population in Kubah National Park, Kuching Prov., Sarawak, Malaysia, and is conspicuously present (Ch'ien Lee, personal communication) in this nature reserve. We assume that its present-day range may well be confined to this National Park. Most primary lowland forest on noncalcareous soil, the habitat of $B$. kubahense, in the wide surroundings has been cleared except for a few relatively well-surveyed reserves in which the species appears to be absent. In addition, other species of section Pahudia are narrow endemics: B. reticulatum Hook.f. and B. signatum J.J. Verm. \& A. Lamb (both from the same region as B. kubahense-the first is a limestone endemic, the second occurs in Kerangas forests; personal observation). We also list B. nabawanense J.J. Wood \& A. Lamb, which has never been found outside the population that provided the type specimen in Sabah in 1983 (Chan et al. 1994).

The beauty of $B$. kubahense and indeed the very fact that it is here described as a new species make it a target for commercial collecting. Actually, an unknown amount of pilfering from the locality has occurred already, because plants have turned up in nurseries in Singapore (Woonleng Nurseries, http://www.woonleng.com/, under the name B. refractilingue). We expect that plants will soon find their way into European amateur greenhouses. Similar cases are known (though not properly documented) from Peninsular Malaysia, where Bulbophyllum thiurum J.J. Verm., an endemic to the Endau Rompin National Park, was traded well before the first author could lay hands on a specimen to formally describe the species. At present, its fate in the wild is unknown. A similar course of events is documented for various Vietnamese Paphiopedilum species (Averyanov et al. 2003, p. 274), a very popular genus in horticulture. It is disheartening to see how these practices spread from 
Paphiopedilum to other, less spectacular orchid groups; no legislation to curb trans-border transfer of material seems able to control the trade in these species. Here, we are presented with a moral issue as taxonomists: describing a new, possibly critically endangered species will increase its commercial value and will further endanger the population. We will advise local authorities to implement measures for protection.

Bulbophyllum kubahense J.J. Verm. \& A. Lamb, sp. nov. (Fig. 1).

B. refractilingue similis, rhachide longiore (3.5-4.8 vs. $0.5-1.7 \mathrm{~cm}$ ), sepalis lateralibus longioribus (ca. $16 \mathrm{vs.}$ $7-10 \mathrm{~mm}$ ), petalis longioribus (ca. $15 \times 11 \mathrm{~mm}$ vs. 5-11 × 3-7.5 mm) distincta.

Type: MALAYSIA, Sarawak: Kubah National Park, S 74287 (Lai Shak Teck) (holotype: SAR!, isotype: L!).
Roots along the entire rhizome. Rhizome $3-5 \mathrm{~mm}$ diameter, sections between pseudobulbs 13-21 cm long, bract fibres moderately persistent. Pseudobulbs distant, cylindrical, 2-3.5 $\times 0.7-0.9 \mathrm{~cm}$. Petiole $2-4 \mathrm{~cm}$. Leaf blade elliptic, 13-2 × 5-9.5 cm, index (length/width) 2.4-2.8; acute to acuminate. Inflorescence patent, a short raceme $9.5-11.5 \mathrm{~cm}$ long, 15 - to 17 -flowered. Peduncle 6-7 cm, bracts ca. 6 , the longest ca. $17 \mathrm{~mm}$ long. Rhachis nodding, 3.5-4.8 cm. Floral bracts ovate, ca. $13 \times 3 \mathrm{~mm}$, acute. Flowers not resupinate, fully opening, many simultaneously. Pedicel and ovary ca. $20 \mathrm{~mm}$ long, basal node + flush with the surface of the rhachis, ovary ribs rounded, straight. Median sepal recurved, obovate, ca. $16 \times 12 \mathrm{~mm}$, index ca. 1.3 ; rounded and shortly apiculate, margins entire, base narrowly attached; thin; glabrous. Lateral sepals free, oblique, recurved to spreading, elliptic,
Fig. 1a-g Bulbophyllum kubahense J.J. Verm. \& A. Lamb. a Habit. b Flower. c Flower analysis, from left to right median sepal, petal, lateral sepals, lip. d Lip, left abaxial side, right adaxial side. e Column and lip, lateral view. f Anther, left adaxial side, right abaxial side. g Pollinia, left a single pair, right two pairs. Drawn by J.J. Vermeulen (C) 2010, from $S 74287$ (herbarium material, a-b partly reconstructed from a colour photograph of unknown origin of a cultivated plant)

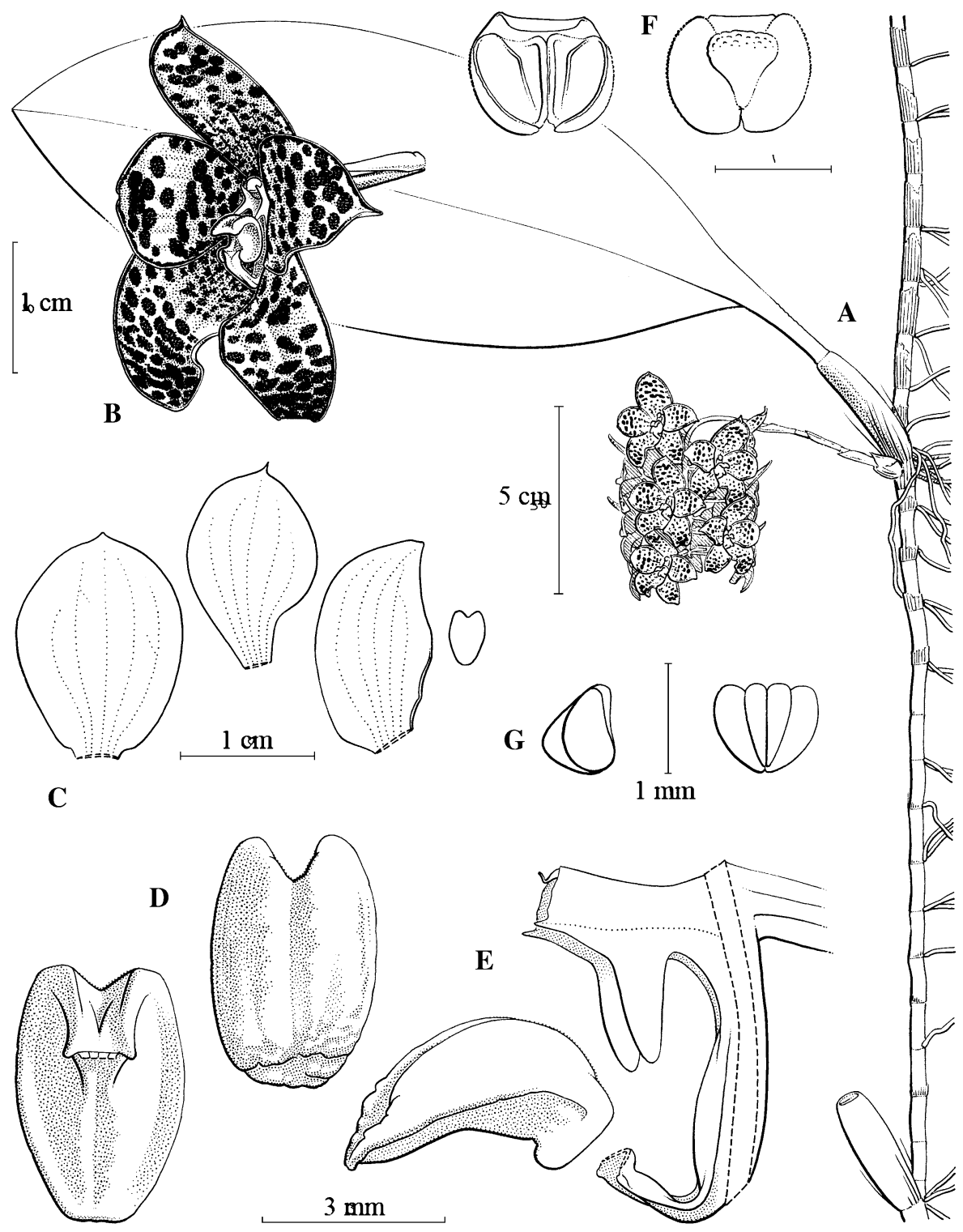


ca. $16 \times 9 \mathrm{~mm}$, index ca. 1.7 , acute, base narrowly attached; otherwise as the median sepal. Petals recurved to spreading, elliptic-obovate, ca. $15 \times 11 \mathrm{~mm}$, index ca. 1.3; rounded and cuspidate with cusp ca. $1 \mathrm{~mm}$ long, margins entire, base narrowly attached; thin, glabrous. Lip slightly recurved, elliptic-ovate, ca. $4.2 \times 2.8 \mathrm{~mm}$, index ca. 1.5 (all without artificial spreading); rounded, margins entire; very thick; adaxially concave near the base, slightly convex near the tip, surface proximally with very fine transverse ribs with rows of minute papillae on their crest which disappear towards the apex of the lip, distally somewhat coarsely rugulose; abaxially with a weak, retuse median ridge over the entire length of the lip, surface smooth. Column ca. $3.8 \mathrm{~mm}$ long, stigma at its base without teeth, column foot without tooth just above the ligament. Stelidia triangular, ca. $0.2 \mathrm{~mm}$, acute, with a patent, slightly falcate, (narrowly) triangular, obtuse tooth along the lower margin, about half-way along the column. Anther abaxially colliculate and with a conical, rounded crest towards the tip; front margin somewhat drawn out, about entire.

Colours sepals and petals white with large reddish purple spots, margins also reddish purple. Lip white, stained with reddish purple, greenish near the base.

Ecology found as epiphyte near the forest floor in lowland dipterocarp forest. Altitude ca. $160 \mathrm{~m}$. Flowering observed in June.

Distribution Malaysia. Sarawak: Kubah National Park near Kuching (only the type specimen seen).
Diagnostic characters Resembles a luxuriant B. refractilingue J.J. Sm. at first sight. [See Vermeulen (1991), p. 273, for information on this species.] B. kubahense is distinct in the longer rhachis $(3.5-4.8 \mathrm{~cm}$ long vs. $0.5-1.7 \mathrm{~cm}$ ), the longer lateral sepals (ca. $16 \mathrm{~mm}$ long vs. $7-10 \mathrm{~mm}$ ), and petals (ca. $15 \times 11$ vs. $5-11 \times$ $3-7.5 \mathrm{~mm})$.

Open Access This article is distributed under the terms of the Creative Commons Attribution Noncommercial License which permits any noncommercial use, distribution, and reproduction in any medium, provided the original author(s) and source are credited.

\section{References}

Averyanov L, Cribb P, Loc PK, Hiep NT (2003) Slipper orchids of Vietnam. Royal Botanic Gardens, Kew

Beaman TE, Wood JJ, Beaman RS, Beaman JH (2001) Orchids of Sarawak. Royal Botanic Gardens, Kew

Chan CL, Lamb A, Shim PS, Wood JJ (1994) Orchids of Borneo, vol. 1. Introduction and a selection of species. Royal Botanic Gardens, Kew

Vermeulen JJ (1991) Orchids of Borneo, vol. 2 Bulbophyllum. Royal Botanic Gardens, Kew

Wood JJ (2001) Dendrochilum of Borneo. Royal Botanic Gardens, Kew

Wood JJ, Cribb PJ (1994) A checklist of the orchids of Borneo. Royal Botanic Gardens, Kew

Wood JJ, Beaman RS, Beaman JH (1993) The plants of mount Kinabalu 2. Orchids. Royal Botanic Gardens, Kew 